Research Article

\title{
Tocotrienol-rich fraction of palm oil exhibits anti-inflammatory property by suppressing the expression of inflammatory mediators in human monocytic cells
}

\author{
Shu-Jing $\mathrm{Wu}^{1}$, Po-Len Liu ${ }^{2}$ and Lean-Teik $\mathrm{Ng}^{3}$ \\ ${ }^{1}$ Department of Health and Nutrition, Chia-Nan University of Pharmacy and Science, Tainan, Taiwan \\ ${ }^{2}$ Department of Respiratory Therapy, Kaohsiung Medical University, Kaohsiung, Taiwan \\ ${ }^{3}$ Department of Biotechnology, Tajen University, Pingtung, Taiwan
}

Tocotrienol-rich fraction (TRF) of palm oil has been shown to possess potent antioxidant, anticancer, and cholesterol lowering activities. In this study, our aim was to examine the effects of TRF on LPSinduced inflammatory response through measuring the production of inflammatory mediators, namely nitric oxide (NO), prostaglandin $\mathrm{E}_{2}\left(\mathrm{PGE}_{2}\right)$, inducible nitric oxide synthase (iNOS), cytokines (TNF- $\alpha$, IL-4, and IL-8), cyclooxygenase-1 and -2 (COX-1 and COX-2), and nuclear factor- $\mathrm{KB}$ (NF$\kappa B$ ) in human monocytic (THP-1) cells. At concentrations $0.5-5.0 \mu \mathrm{g} / \mathrm{mL}$, TRF dose-dependently protected against LPS-induced cell death. At same concentrations, TRF also showed potent antiinflammatory activity as demonstrated by a dose-dependent inhibition of LPS $(1 \mu \mathrm{g} / \mathrm{mL})$-induced release of $\mathrm{NO}$ and $\mathrm{PGE}_{2}$, and a significant decrease in the transcription of proinflammatory cytokines. TRF at $1.0 \mu \mathrm{g} / \mathrm{mL}$ significantly blocked the LPS induction of iNOS and COX-2 expression, but not COX-1. This anti-inflammatory activity was further supported by the inhibition of NF- $\kappa \mathrm{B}$ expression. These results conclude that TRF possesses potent anti-inflammatory activity, and its mechanism of action could be through the inhibition of iNOS and COX-2 production, as well as NF-kB expression.

Keywords: COX-2 / Cytokines / NF-kB / THP-1 cells / Tocotrienols

Received: October 11, 2007; revised: November 13, 2007; accepted: November 15, 2007

\section{Introduction}

Chronic inflammations and infections are known to upregulate a series of enzymes and signaling proteins in affected tissues and cells. Among the proinflammatory enzymes, the inducible forms of nitric oxide synthase (iNOS) and cyclooxygenase (COX), are responsible for increasing the levels

Correspondence: Professor Lean-Teik Ng, Department of Biotechnology, Tajen University, No. 20 Weishin Road, Yanpu Shiang, Pingtung, Taiwan

E-mail: 1thuang@mail.tajen.edu.tw

Fax: +886-8-7621645

Abbreviations: COX, cyclooxygenase; EMSA, electrophoretic mobility shift assay; FBS, fetal bovine serum; HEPES, $N$-(2-hydroxyethyl)piperazine- $N^{\prime}$ - (2-ethenesulfonic acid); iNOS, inducible nitric oxide synthase; MTT, 3-(4,5-dimethyl-thiazol-2-yl)-2,5-diphenyl-tertazolium bromide; NF-кB, nuclear factor-кB; NSAID, nonsteroidal antiinflammatory drug; $\mathbf{P G E}_{2}$, prostaglandin $\mathrm{E}_{2}$; TRF, Tocotrienol-rich fraction of nitric oxide $(\mathrm{NO})$ and prostaglandin $\mathrm{E}_{2}\left(\mathrm{PGE}_{2}\right)$. They are known to be involved in various chronic diseases including multiple sclerosis, Parkinson's and Alzheimer's diseases, and colon cancer [1]. LPS, which is a component of the cell walls of Gram-negative bacteria, can activate a number of cellular signals of macrophages, hepatocytes, and monocytes during inflammation and infection [2,3].

$\mathrm{PGE}_{2}, \mathrm{COX}-2$, and iNOS have been widely used to determine the anti-inflammatory effects of potential therapeutic products. There are two isoforms of COX, namely COX-1 and COX-2. COX-1 is a constitutively expressed form in normal physiological functions, whereas COX-2 is expressed only in response to inflammatory signals such as cytokines and bacterial endotoxin LPS $[4,5]$. At present, a majority of clinically used nonsteroidal anti-inflammatory drugs (NSAIDs) have been shown in vitro to be either selective COX-1 or dual COX-1/COX-2 inhibitors $[6,7]$. They were shown to have varying degrees of gastric and renal side effects [8]. It was therefore suggested that the selective 
inhibition of COX-2 to be a better strategy for treating inflammation.

Nuclear factor $-\kappa \mathrm{B}(\mathrm{NF}-\kappa \mathrm{B})$ is a transcription factor that regulates the expression of multiple immune and inflammatory genes [9]. When stimulated by external stimuli, including LPS, it can lead to the coordinated expression of inflammatory responses. Activated NF- $\kappa \mathrm{B}$ has now recognized to link with a variety of inflammatory diseases such as cancer, asthma, psoriasis, rheumatoid arthritis, and others $[9,10]$. The important role of NF- $\kappa \mathrm{B}$ in the pathogenesis of inflammation suggests that inhibitors of NF- $\mathrm{B}$ pathway could be an effective target in treating human inflammatory diseases.

Palm oil, an edible vegetable oil derived from the fruits of Elaeis guineensis, forms an important component of the human diet in different parts of the world. It has 50\% saturated, $40 \%$ monosaturated, and 10\% PUFAs besides an abundant amount of phytonutrients $[11,12]$. Tocotrienols, bioactive components of palm oil, are effective in controlling anthrosclerosis and certain types of cancer [13-16]. They were also shown to be active against oxidative damage to lipids in vitro and in vivo $[17,18]$, as well as activity in neuroprotection [19, 20]. Furthermore, tocotrienol-rich fraction (TRF) from palm oil was reported to be more potent than $\alpha$-tocopherol against oxidative damage in brain mitochondria [21], and more effective in inhibiting protein oxidation and lipid peroxidation in liver microsomes [22]. TRF also possessed activities such as anticancer [13-15, 23], cardiovascular protective $[18,24]$, and blood cholesterol lowering $[24,25]$ effects. Recently, $\gamma$-tocotrienol, but not $\gamma$ tocopherol, was shown to possess the inhibitory effect on the NF- $\kappa \mathrm{B}$ activation pathway, and consequently triggering the downregulation of various gene products and potentiation of apoptosis [26]. To further examine the anti-inflammatory property and mechanism(s) of action of tocotrienols, in this study we investigated the effects of TRF from palm oil on LPS-induced inflammatory response through measuring the $\mathrm{NO}$ release, $\mathrm{PGE}_{2}$ production, cytokines (TNF- $\alpha$, IL-4, and IL-8) formation, iNOS, COX-1, COX-2, and NF- $\kappa \mathrm{B}$ expression in human monocytic (THP-1) cells.

\section{Materials and methods}

\subsection{Chemicals}

DMSO, penicillin, streptomycin, anti- $\beta$ actin, 3-(4,5dimethyl-thiazol-2-yl)-2,5-diphenyl-tertazolium bromide (MTT), and LPS (which was obtained from Escherichia coli strain O55:B5) were purchased from Sigma Chemical (St. Louis, MO, USA). Fetal bovine serum (FBS) and RPMI-1640 medium were obtained from Gibco BRL (Gaithersburg, MD, USA). The ELISA kit used for the determination of $\mathrm{PGE}_{2}$ was purchased from Alexis Biochemicals (Cayman Chemical, Ann Arbor, MI, USA). Human TNF- $\alpha$, IL-4, and IL-8 ELISA kits were obtained from Raybiotech
(Norcross, GA, USA). The anti-iNOS, anti-COX-1, antiCOX-2, and anti-NF- $\kappa$ B bodies were purchased from Santa Cruz Biotechnology (Santa Cruz, CA, USA). Antimouse IgG antibody was obtained from Promega (Madison, WI, USA). All other chemicals and reagents used were of analytical grade.

\subsection{TRF from palm oil}

TRF of palm oil (also known as Tocomin ${ }^{\circledR}$ ) was supplied by Carotech (Malaysia). It consists of $15.38 \% \alpha$-tocotrienol, $28.20 \% \gamma$-tocotrienol, $6.42 \% \delta$-tocotrienol, $15.34 \% \alpha$-tocopherol, $12.82 \%$ plant squalene, and $5.12 \%$ phytosterol. All experiments were conducted using TRF obtained from the same batch.

\subsection{Cell culture}

THP-1, a promonocytic cell line, was obtained from the American Type Culture Collection (ATCC No. TIB-202; Manassas, VA, USA). Cells were grown in RPMI-1640 medium containing 10\% heat-inactivated FBS, 100 units/ $\mathrm{mL}$ penicillin and $100 \mu \mathrm{g} / \mathrm{mL}$ streptomycin. They were maintained at $37^{\circ} \mathrm{C}$ in a humidified atmosphere of $5 \% \mathrm{CO}_{2}$.

\subsection{MTT and trypan blue assay for cell viability}

Cell viability was examined using MTT and trypan blue assays. In brief, THP- 1 cells were cultured at $1 \times 10^{5}$ cells per well in 96-well plates containing $100 \mu \mathrm{L}$ of RPMI-1640 medium. After an overnight incubation, cells were treated with $1 \%$ DMSO (control) or LPS $(1 \mu \mathrm{g} / \mathrm{mL})$ alone or LPS $(1 \mu \mathrm{g} / \mathrm{mL})$ plus various concentrations of TRF $(0.5,1.0$, and $5.0 \mu \mathrm{g} / \mathrm{mL}$ ), followed by incubating the plates for $24 \mathrm{~h}$. For MTT assay, cells were washed once before adding $50 \mu \mathrm{L}$ of FBS-free medium containing $5 \mathrm{mg} / \mathrm{mL}$ MTT. After incubating at $37^{\circ} \mathrm{C}$ for $4 \mathrm{~h}$, the medium was discarded and the formazan blue that formed in the cells was dissolved in DMSO. The OD was measured at $550 \mathrm{~nm}$. For trypan blue assay, the number of viable cells was determined by staining cell populations with trypan blue. One part of $0.4 \%$ trypan blue dissolved in PBS was added to the cell suspension, and the number of unstained (viable) cells was counted using a hemocytometer.

\subsection{Nitrite determination}

After incubating the cells with either LPS $(1 \mu \mathrm{g} / \mathrm{mL})$ or LPS plus various concentrations of $\operatorname{TRF}(0.5,1.0$, and $5.0 \mu \mathrm{g} / \mathrm{mL}$ ) for $24 \mathrm{~h}$, the supernatant was removed from the cultures. The nitrite accumulated in culture medium was measured as an indicator of NO production based on the Griess reaction [27]. Briefly, $100 \mu \mathrm{L}$ of each supernatant was mixed with the same volume of Griess reagent ( $1 \%$ sulfanilamide in $5 \%$ phosphoric acid and $0.1 \%$ naphthylethy- 
lenediamine dihydrochloride in water, and then incubated at room temperature for $10 \mathrm{~min}$, the absorbance was measured at $550 \mathrm{~nm}$ using an ELISA reader. The amount of NO production in samples was determined basing on the sodium nitrite serial dilution standard curve.

\section{6 $\mathrm{PGE}_{2}$ assay}

The $\mathrm{PGE}_{2}$ level in the supernatant of the culture medium was quantified using ELISA kits and conducted according to the manufacturer instructions.

\subsection{Measurement of cytokines}

The proinflammatory cytokines (TNF- $\alpha$, IL-4, and IL-8) were measured using ELISA kits and performed according to the manufacturer instructions.

\subsection{Cytoplasmic extract preparation}

Cytoplasmic extracts were prepared as described previously [28]. In brief, after cells were treated without and with LPS $(1 \mu \mathrm{g} / \mathrm{mL})$ alone or LPS plus TRF $(1 \mu \mathrm{g} / \mathrm{mL})$, they were washed once with PBS then lysed in ice-cold buffer I (10 mM $\quad N$-(2-hydroxyethyl)piperazine- $N$ '-(2-ethenesulfonic acid) (HEPES), pH 8.0, 1 mM EDTA, $1 \mathrm{mM}$ ethylene glycol tetraaccetic acid (EGTA), 1 mM DTT, $0.4 \mathrm{M}$ sodium chloride, $1 \mathrm{mM}$ PMSF) containing $2.0 \mu \mathrm{g} / \mathrm{mL}$ leupeptin, $2.0 \mu \mathrm{g} / \mathrm{mL}$ aprotonin, and $0.5 \mathrm{mg} / \mathrm{mL}$ benzamidine (Sigma Chemical). The cells were incubated on ice for $20 \mathrm{~min}$, followed by adding $10.0 \mu \mathrm{L}$ of $10 \%$ Nonidet P-40. After centrifuging the lysates at $10000 \times g$ at $4^{\circ} \mathrm{C}$ for $10 \mathrm{~min}$, the supernatant collected was used as the cytoplasmic extract. It was then stored at $-80^{\circ} \mathrm{C}$ until use. Protein concentration in these extracts was determined by BioRad reagents (BioRad Laboratories, Hercules, CA, USA).

\subsection{Western immunoblot analysis}

Western blot analysis of cytoplasmic iNOS, COX-1, COX-2, and NF- $\kappa \mathrm{B}$ were carried out by employing the respective antibodies. In brief, cytoplasmic proteins $(50 \mu \mathrm{g} /$ lane $)$ were loaded onto SDS-polyacrylamide gels and electrophoretically transferred to a PVDF membrane (BioRad Laboratories). After inhibiting the nonspecific-binding sites with 5\% w/v skim milk in $0.1 \% \mathrm{v} / \mathrm{v}$ Tween 20 containing PBS (PBST) for $1 \mathrm{~h}$ at room temperature, the membrane was incubated with specific primary antibodies (namely anti-COX-1 (1:500; an affinity purified goat polyclonal antibody), anti-COX-2 (1:500; an affinity purified goat polyclonal antibody), antiiNOS (1:500; an affinity purified rabbit polyclonal antibody), anti-NF- $\mathrm{BB}(1: 500$; an affinity purified mouse $\mathrm{mAb})$, and anti- $\beta$-actin (1:5000; an affinity purified mouse $\mathrm{mAb}$ ) antibodies) for $1 \mathrm{~h}$ at room temperature. Antibody recogni- tion was detected with antimouse IgG antibody linked to the horseradish peroxidase. Antibody-bound proteins were detected by the ECL western blotting analysis system (Amersham, Aylesbury, UK). The expression of $\beta$-actin was used as a control.

\subsection{Nuclear extract preparation and electrophoretic mobility shift assay (EMSA)}

Nuclear protein extracts were prepared as described previously [29]. Briefly, after washing with PBS, cells were scraped off the plates in $0.6 \mathrm{~mL}$ ice-cold buffer A $(10 \mathrm{mM}$ HEPES, pH 7.9, $10 \mathrm{mM} \mathrm{KCl,} 1$ mM DTT, 1 mM PMSF, $1.5 \mathrm{mM} \mathrm{MgCl}_{2}$, and $2 \mu \mathrm{g} / \mathrm{mL}$ each of aprotinin, pepstatin, and leupeptin). After centrifugation at $300 \times g$ at $4{ }^{\circ} \mathrm{C}$ for $10 \mathrm{~min}$, cells were suspended in buffer B $(80 \mu \mathrm{L}$ of $0.1 \%$ Triton X-100 in buffer A) and then left on ice for $10 \mathrm{~min}$, followed by centrifuging at $12000 \times g$ at $4{ }^{\circ} \mathrm{C}$ for $10 \mathrm{~min}$. The nuclear pellets collected were resuspended in $70 \mu \mathrm{L}$ ice-cold buffer C (20 mM HEPES, pH 7.9, $1.5 \mathrm{mM} \mathrm{MgCl}_{2}$, $0.42 \mathrm{M} \mathrm{NaCl}, 1 \mathrm{mM}$ DTT, $0.2 \mathrm{mM}$ EDTA, $1 \mathrm{mM}$ PMSF, $25 \%$ glycerol, and $2 \mu \mathrm{g} / \mathrm{mL}$ each of aprotinin, pepstatin, and leupeptin), and then incubated for $30 \mathrm{~min}$ at $4^{\circ} \mathrm{C}$, followed by centrifuging at $15000 \times g$ at $4^{\circ} \mathrm{C}$ for $30 \mathrm{~min}$. The resulting supernatant was used as the nuclear extract, which was stored at $-80^{\circ} \mathrm{C}$ until use. Protein concentrations were determined by BioRad reagents. The NF- $\kappa$ B and AP1 consensus oligonucleotide together with the Gel Shift Assay System was supplied by Promega.

\subsection{Statistical analysis}

Data were presented as means \pm SDs from three independent experiments. Statistical comparisons of means were performed by one way ANOVA, followed by the Duncan's multiple range test (SAS Institute, Cary, NC, USA). Differences were considered significant when $p$-value was $<0.05$.

\section{Results}

\subsection{Effect of TRF on the THP-1 cell viability}

In order to determine whether TRF causes toxicity on THP1 cells, cells were treated with TRF at various concentrations $(0.5,1.0$, and $5.0 \mu \mathrm{g} / \mathrm{mL})$ with or without LPS, and then examined by MTT and trypan blue assays. Results showed that TRF alone at concentrations $0.5-5 \mu \mathrm{g} / \mathrm{mL}$ were not toxic to THP-1 cells (Figs. 1A and B). At concentrations 1.0 and $5.0 \mu \mathrm{g} / \mathrm{mL}$, TRF also significantly protected against LPS-induced cytotoxicity in THP-1 cells. As cell viability was completely protected by $1.0 \mu \mathrm{g} / \mathrm{mL} \mathrm{TRF}$, this concentration was therefore selected for further molecular studies of anti-inflammatory property and mechanism(s) of action in THP-1 cells. 
A. Trypan blue assay

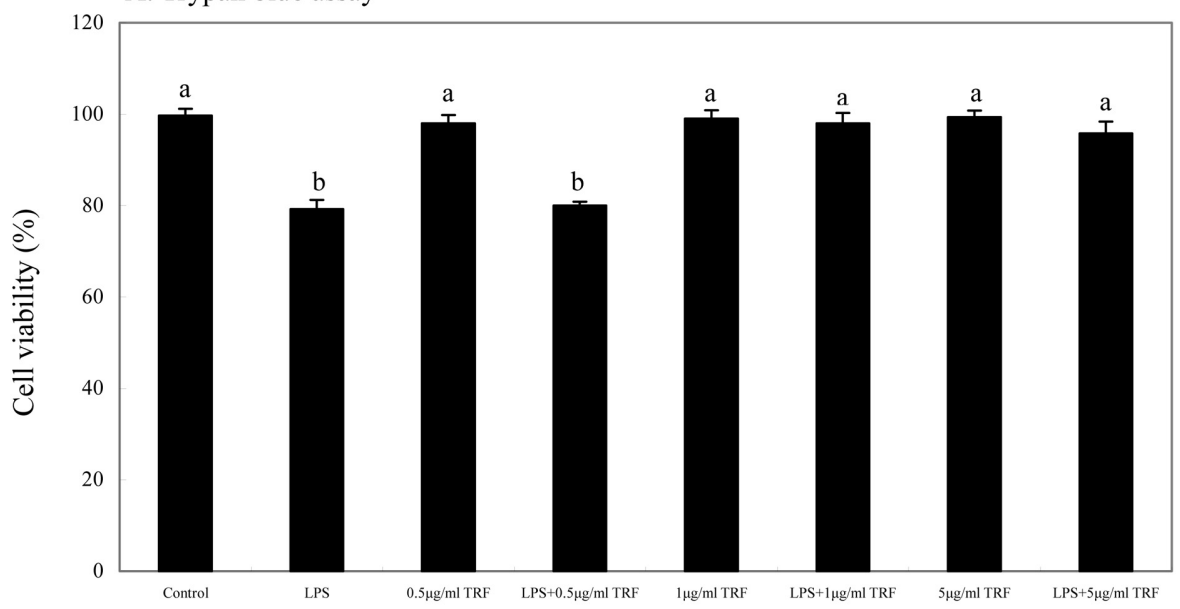

B. MTT assay

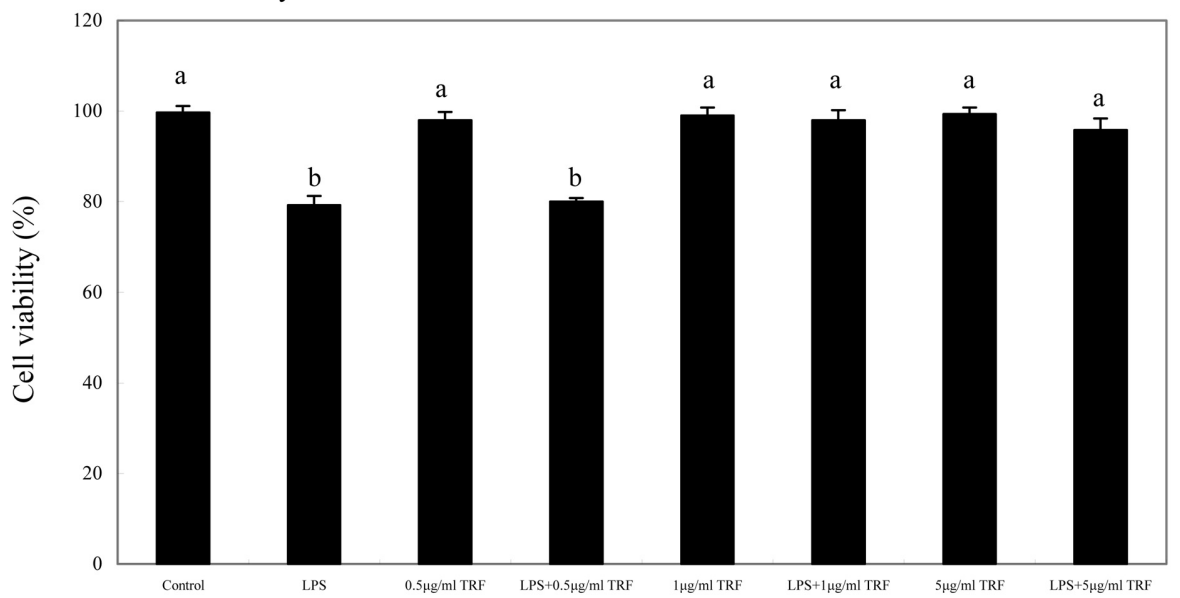

Figure 1. Effect of TRF on human monocytic cell (THP-1) viability. Cells were stimulated with LPS $(1 \mu \mathrm{g} / \mathrm{mL})$ for $24 \mathrm{~h}$ in the absence or presence of TRF at various concentrations $(0.5,1.0$, and $5.0 \mu \mathrm{g} / \mathrm{mL})$. Cell viability was analyzed by trypan blue and MTT assays. Each data represents the mean $\pm S D$ of three independent experiments. Bars not denoted by the same letter differ significantly at $p<0.05$ as analyzed by Duncan's multiple range test.

\subsection{Effect of TRF on NO production}

To assess the effect of TRF on LPS-induced NO production in THP-1 cells, cell culture medium was harvested, and the concentration of accumulated nitrite in the culture medium was estimated by the Griess method. Results showed that NO concentration markedly increased about nine-fold $(\sim 48 \mu \mathrm{M})$ after LPS-stimulation (Table 1). Coincubation of cells with LPS plus TRF $(0.5,1.0$, and $5.0 \mu \mathrm{g} / \mathrm{mL})$ resulted in an obvious concentration-dependent reduction of $\mathrm{NO}$ formation. Interestingly, cells incubated with $5.0 \mu \mathrm{g} / \mathrm{mL}$ TRF exhibited a similar level of NO in the medium as that of the control.

\subsection{Effect of TRF on $\mathrm{PGE}_{2}$ synthesis}

$\mathrm{PGE}_{2}$ release is an important indicator of inflammatory response in cells. An increase in $\mathrm{PGE}_{2}$ production $(42.67 \pm 3.68 \mathrm{ng} / \mathrm{mL})$ was shown at $24 \mathrm{~h}$ after LPS $(1 \mu \mathrm{g} /$
$\mathrm{mL}$ ) treatment. Cotreatment of cells with LPS plus TRF at various concentrations $(0.5,1.0$, and $5.0 \mu \mathrm{g} / \mathrm{mL})$ significantly suppressed the LPS-induced $\mathrm{PGE}_{2}$ production (Table 1), with a considerable drop in $\mathrm{PGE}_{2}$ production was noted in the 1.0 and $5.0 \mu \mathrm{g} / \mathrm{mL}$ TRF-treated groups.

\subsection{Attenuation of LPS-induced cytokines formation}

To determine the effect of TRF on the production of proinflammatory cytokines such as TNF- $\alpha$, IL- 4 , and IL-8 cells were treated with control $(0.1 \%$ DMSO $)$ and TRF $(0.5,1.0$, and $5.0 \mu \mathrm{g} / \mathrm{mL})$ in the presence or absence of LPS $(1 \mu \mathrm{g} /$ $\mathrm{mL}$ ) for $24 \mathrm{~h}$. The cytokine levels presence in the media were measured by ELISA kits. LPS-treated cells showed a marked upregulation of TNF- $\alpha$, IL- 4 , and IL-8 production, however, they were inhibited by pretreatment with TRF (Table 2). The greatest inhibitory effect on proinflamma- 

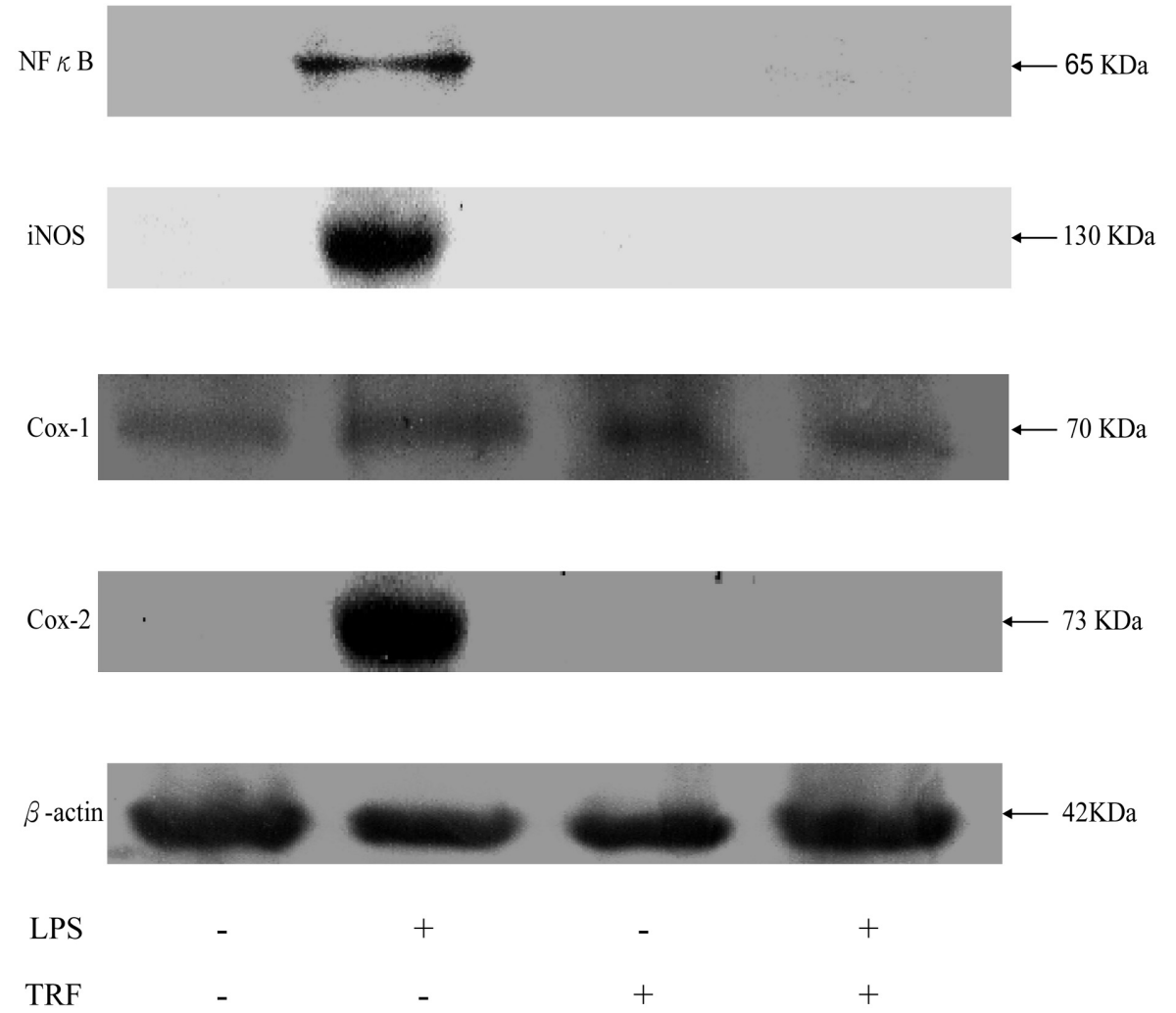

Figure 2. Effect of TRF on cytoplasmic iNOS, COX-1, COX-2, and NF-kB expression. THP-1 cells were stimulated with LPS $(1 \mu \mathrm{g} / \mathrm{mL})$ for $24 \mathrm{~h}$ in the presence or absence of TRF $(1 \mu \mathrm{g} / \mathrm{mL})$. The levels of iNOS, COX-1, COX-2, and $\mathrm{NF}-\kappa \mathrm{B}$ in the cytosolic protein were determined by Western blotting assay. $\beta$-Actin was used as loading control.
Table 1. Effects of TRF on LPS $(1 \mu \mathrm{g} / \mathrm{mL})$-induced NO release and $\mathrm{PGE}_{2}$ production in THP-1 cells

\begin{tabular}{lcr}
\hline Treatments & Nitric oxide $(\mu \mathrm{M})$ & $\mathrm{PGE}_{2}(\mathrm{ng} / \mathrm{mL})$ \\
\hline Control & $5.62 \pm 0.64^{\mathrm{d}}$ & $5.60 \pm 0.45^{\mathrm{d}}$ \\
LPS & $48.02 \pm 1.78^{\mathrm{a}}$ & $42.67 \pm 3.68^{\mathrm{a}}$ \\
LPS $+0.5 \mathrm{mg} / \mathrm{mL}$ TRF & $26.50 \pm 3.26^{\mathrm{b}}$ & $16.93 \pm 1.72^{\mathrm{b}}$ \\
LPS $+1.0 \mathrm{mg} / \mathrm{mL}$ TRF & $8.24 \pm 0.57^{\mathrm{c}}$ & $7.53 \pm 0.41^{\mathrm{c}}$ \\
LPS $+5.0 \mathrm{mg} / \mathrm{mL}$ TRF & $7.93 \pm 0.74^{\mathrm{d}}$ & $8.43 \pm 0.67^{\mathrm{c}}$ \\
\hline
\end{tabular}

Each data represents the mean $\pm S D$ of three independent experiments. Values within a column followed by a common superscript letter are not significantly different at $p<0.05$ as analyzed by Duncan's multiple range test.

tory cytokines production appeared to be at 1 and $5 \mu \mathrm{g} / \mathrm{mL}$ of TRF.

\subsection{Effect of TRF on cytosolic iNOS, COX-1, COX- 2, and NF-кB expression}

With the assumption that the inhibition of $\mathrm{NO}$ and $\mathrm{PGE}_{2}$ production by TRF in THP-1 cells would be caused by a decrease in the iNOS, COX-2, and NF- $\kappa \mathrm{B}$ proteins, the effect of TRF on iNOS, COX-1, COX-2, and NF- $\kappa$ B protein expression was examined in cells treated with or without LPS $(1 \mu \mathrm{g} / \mathrm{mL})$ for $24 \mathrm{~h}$. Western blotting analysis indicated that the expression of iNOS, COX-1, COX-2, and NF- $\mathrm{BB}$ were upregulated after LPS stimulation (Fig. 2). Cotreat- ment of cells with LPS plus $1 \mu \mathrm{g} / \mathrm{mL}$ TRF for $24 \mathrm{~h}$ significantly inhibited iNOS and COX-2 expression, but the protein level of COX-1 was not affected. TRF also significantly suppressed the expression of NF- $\mathrm{KB}$.

\subsection{Effect of TRF on nuclear NF-кB expression}

The effect of TRF on the activation of nuclear NF- $\kappa B$ expression was examined by using EMSA. Results showed that the nuclear extracts from LPS-stimulated THP-1 cells yielded a large band in comparison to the unstimulated cells, and exhibited DNA-binding activity to the NF- $\kappa$ B site containing oligonucleotide (Fig. 3). However, the nuclear extracts of TRF-treated cells showed a marked reduction in the DNA-protein complex-binding activity, as evidenced by a decrease in the intensity of this band. Cotreatment of cells with LPS plus TRF showed an inhibitory effect on the activation of NF- $\kappa \mathrm{B}$ as demonstrated by a decrease in the $\mathrm{NF}-\kappa \mathrm{B}$ protein expression.

\section{Discussion}

The present study demonstrates that TRF is an effective inhibitor of LPS-induced $\mathrm{NO}$ generation, $\mathrm{PGE}_{2}$ production, cytokines (TNF- $\alpha$, IL-4, and IL-8) secretion, iNOS, COX2 , and NF- $\kappa \mathrm{B}$ expression in THP-1 cells. TRF suppressed $\mathrm{PGE}_{2}$ production by downregulating the COX-2 and iNOS 
Table 2. Effects of TRF on LPS ( $1 \mu \mathrm{g} / \mathrm{mL})$-induced IL-4, IL-8, and TNF- $\alpha$ formation in THP-1 cells

\begin{tabular}{lccc}
\hline & \multicolumn{3}{c}{ Concentration $(\mathrm{pg} / \mathrm{mL})$} \\
\cline { 2 - 4 } Treatments & TNF- $\alpha$ & $\mathrm{IL}-4$ & $\mathrm{IL}-8$ \\
\hline Control & $139.07 \pm 0.02^{\mathrm{d}}$ & $84.63 \pm 3.42^{\mathrm{c}}$ & $161.33 \pm 7.36^{\mathrm{d}}$ \\
LPS & $3594.20 \pm 13.02^{\mathrm{a}}$ & $1362.67 \pm 36.57^{\mathrm{a}}$ & $2498.00 \pm 28.61^{\mathrm{a}}$ \\
LPS $\pm 0.5 \mathrm{mg} / \mathrm{mL}$ TRF & $1213.50 \pm 70.83^{\mathrm{b}}$ & $310.67 \pm 8.22^{\mathrm{b}}$ & $619.50 \pm 9.01^{\mathrm{b}}$ \\
LPS $\pm 1.0 \mathrm{mg} / \mathrm{mL}$ TRF & $181.50 \pm 13.53^{\mathrm{c}, \mathrm{d}}$ & $108.90 \pm 6.80^{\mathrm{c}}$ & $193.17 \pm 5.57^{\mathrm{c}, \mathrm{d}}$ \\
LPS $\pm 5.0 \mathrm{mg} / \mathrm{mL}$ TRF & $243.77 \pm 5.06^{\mathrm{c}}$ & $95.67 \pm 11.44^{\mathrm{c}}$ & $228.00 \pm 14.09^{\mathrm{c}}$ \\
\hline
\end{tabular}

Each data represents the mean $\pm S D$ of three independent experiments. Values within a column followed by a common superscript letter are not significantly different at $p<0.05$ as analyzed by Duncan's multiple range test.

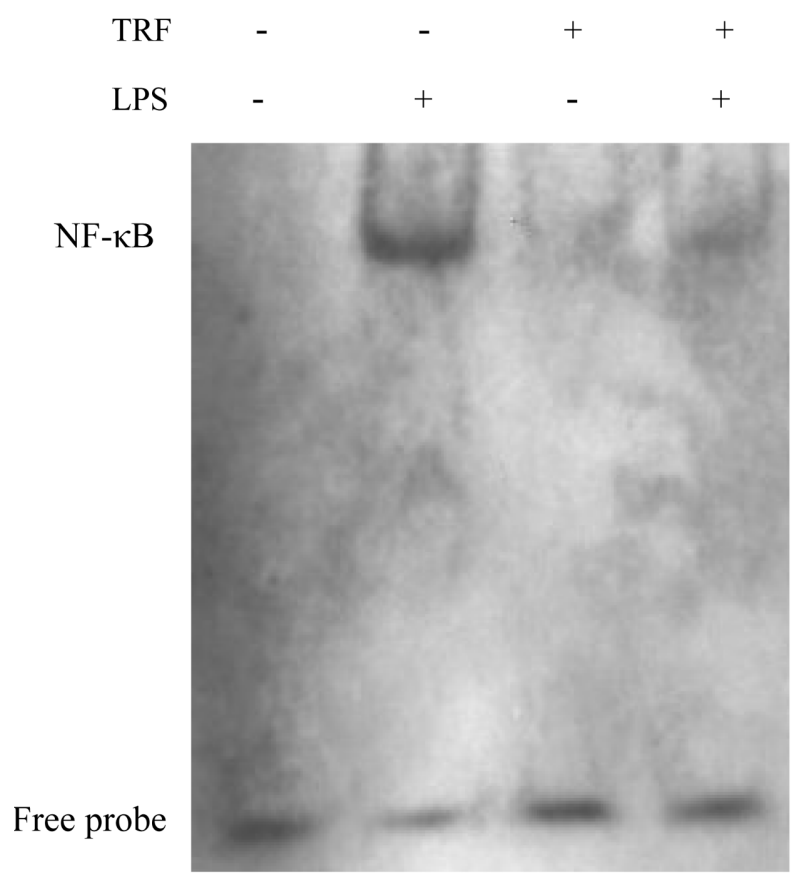

Figure 3. Effect of TRF on NF-kB expression in the nuclear protein. After stimulating the THP-1 cells with LPS $(1 \mu \mathrm{g} / \mathrm{mL})$ for $24 \mathrm{~h}$ in the presence or absence of TRF $(1 \mu \mathrm{g} / \mathrm{mL})$, nuclear extracts were prepared and analyzed for NF- $\mathrm{KB}$ activation by EMSA.

expression in a dose-dependent manner. This is the first time that TRF from palm oil was shown to possess potent anti-inflammatory activity through blocking NF- $\kappa \mathrm{B}$ activation and selectively inhibiting the COX-2 expression, and this activity was not attributable to the cytotoxicity of TRF as assessed by the MTT and trypan blue assays.

Palm oil has traditionally been used as cooking oil, while TRF has been consumed as dietary supplement for prevention of breast cancer [13, 14], and lowering blood cholesterol and lipid [24, 25]. Its main bioactive components were reported to be tocotrienols [13, 24, 30]. Studies have shown that TRF possesses antioxidant [17, 18, 23], anticancer $[13-15,23]$, and cardiovascular protective $[18,24]$ activ- ities. In this study, we demonstrated that TRF possesses potent anti-inflammatory activity and its mode of action could be through the inhibition of iNOS, COX-2, and NF$\kappa \mathrm{B}$ expression.

Inflammation is a complex process, which involves numerous mediators of cellular and plasma origins. LPS injection has been shown to stimulate plasma and tissue cytokine formation, iNOS expression, and NO production in vivo [31, 32]. Similarly, LPS also stimulated a dramatic increase in NO production in THP-1 cells. Inhibitors of iNOS were suggested to provide protection against LPSinduced hepatic toxicity [33]. Natural antioxidants such as curcumin [34], resveratrol [27], and tea polyphenols [35] have been shown to exhibit inhibitory effects on LPSinduced iNOS expression and hepatic damage. Therefore, they were considered as potential effective therapeutics for preventing inflammatory response and diseases [36]. In this study, TRF markedly decreased the expression of iNOS and COX-2 at a low concentration level, together with its antioxidant activity [17, 18, 22], which may have contributed to the potent anti-inflammatory activity.

Studies on other forms of vitamin E showed that tocopherols act anti-inflammatory at post-transcriptional level by inhibiting either COX or 5-lipoxygenase (LOX) activity [37]. $\alpha$-Tocopherol was shown to be much less potent than $\gamma$-tocopherol in reducing $\mathrm{PGE}_{2}$ in RAW 264.7 macrophages and human lung epithelial cells (A549). Furthermore, $\gamma$-tocopherol but not $\alpha$-tocopherol, was reported to be effective in inhibiting COX-2 activity in LPS-activated macrophages and IL-1 $\beta$-treated epithelial cells [38]. As for the form of vitamin $\mathrm{E}$ used in this study, TRF, which contains tocotrienols and $\alpha$-tocopherol, but not $\gamma$-tocopherol, suggesting that the potent anti-inflammatory activity of TRF could be mainly contributed by $\alpha-, \gamma$-, and $\delta$-tocotrienols.

Much evidence have suggested that overexpression of COX-2 is strongly related to pathophysiological diseases including inflammation, cancer, multiple sclerosis, and Alzheimer's disease [39]. $\mathrm{PGE}_{2}$, a major metabolite of the COX-2 pathway, has been implicated in the pathogenesis of acute and chronic inflammatory disease state [40]. On the basis of this information, efforts have been made to develop 
inhibitors or suppressors for the activity or expression of COX-2. In this study, we showed that TRF markedly suppressed the $\mathrm{PGE}_{2}$ release, which was related to the downregulation of COX-2 expression. Interestingly, at concentration as low as $1 \mu \mathrm{g} / \mathrm{mL}$, TRF can also strongly suppress the COX-2 expression while having no effect on COX-1. This is in contrast to the most widely used NSAIDs for inflammation and pain, of which have been reported to cause potential gastrointestinal and renal side effects due to their inhibition on the housekeeping COX-1 enzyme activity [68]. TRF, with its specific inhibition of COX-2 expression, has demonstrated its potential as COX-2 inhibitor and as a good candidate for developing anti-inflammatory drugs.

Anti-inflammatory drugs, such as NSAIDs, glucocorticoids, and immunosuppressants, are known to act as inhibitors of the NF- $\mathrm{BB}$ pathway and the expression of various inflammation-associated genes such as iNOS, COX-2, and TNF- $\alpha[41,42]$. NF- $\kappa$ B regulates the transcription of various proinflammatory cytokines, such as IL-1, $-2,-6$, and -8 , and TNF- $\alpha$, that are involved in the development of various inflammatory lesions [3, 43]. Clinically, the use of NSAIDS was reported to increase in cardiovascular risk [44] and other side-effects [8]. Therefore, selective inhibitors of the NF- $\kappa \mathrm{B}$ pathway were considered to be a better anti-inflammatory drug $[45,46]$. In this study, we showed that TRF significantly inhibited TNF- $\alpha$, IL- 4 , and IL- 8 expression, which could be resulted from the blocking of NF- $\mathrm{B}$ expression in LPS-induced THP-1 cells. This finding further supports that TRF is a good candidate for preventing inflammatory diseases.

Recent studies showed that $\gamma$-tocotrienol, but not $\gamma$-tocopherol, possessed the ability to suppress the activation of $\mathrm{NF}-\kappa \mathrm{B}$ by carcinogens, growth factors, and inflammatory stimuli through inhibition of IKK activation, IкBa phosphorylation, I $\mathrm{Ba}$ degradation, p65 phosphorylation, and NF- $\kappa \mathrm{B}-d e p e n d e n t$ reporter gene expression [26], these events consequently downregulated the expression of NF$\kappa \mathrm{B}$-dependent gene products involved in cell proliferation, antiapoptosis, invasion, and angiogenesis. In this study, we demonstrated that TRF, which contains $\alpha-, \gamma$-, and $\delta$-tocotrienols, possessed potent activity in inhibiting iNOS, COX-2, and NF- $\kappa \mathrm{B}$ expression in LPS-stimulated THP-1 cells. Its inhibitory effect on LPS-induced NF- $\kappa \mathrm{B}$ activity can be further supported by a lesser NF- $\kappa B$ DNA-binding activity in the nuclei of TRF-treated cells than untreated cells. These results confirm that the anti-inflammatory mechanism of TRF could be through the inhibitory effect on iNOS and COX-2 production, and NF- $\kappa \mathrm{B}$ expression.

Studies have shown that both tocotrienols and tocopherols are metabolized similarly in cells [47]. However, tocotrienols were found to degrade much faster than tocopherols. Under different food states, it was found that plasma levels of $\alpha-, \gamma$-, and $\delta$-tocotrienols increase markedly with food intake [48]. In response to supplementation, O'Byrne et al. [49] reported that the concentrations of tocotrienols in the plasma were $0.98,0.54$, and $0.09 \mu \mathrm{M}$ for $\alpha-, \gamma-$, and $\delta$ tocotrienol, respectively. In other studies, tocotrienols in plasma were reported to reach $1 \mu \mathrm{M}$ in humans $[48,50]$ and between 3 and $20 \mu \mathrm{M}$ in various animal species [51-53]. They were mainly found distributing in adipose tissues, skin, and heart [54-56]. Based on cell culture and animal studies, the dosage of tocotrienols for preventing and treating diseases was suggested to be 50-200 mg/day [57].

In conclusion, we have demonstrated that TRF possesses potent anti-inflammatory activity as demonstrated by its inhibitory effects on proinflammatory cytokines formation, $\mathrm{NO}$ generation, $\mathrm{PGE}_{2}$ production, iNOS, COX-2, and NF$\kappa \mathrm{B}$ expression in LPS-stimulated THP-1 cells. These findings provide the first pharmacological evidence on the antiinflammatory property of TRF, and also suggest the potential use of TRF in the prevention of inflammatory diseases.

The authors would like to thank Mr. David Ho (Carotech Ltd., Malaysia) for generously providing the tocotrienolrich fraction of palm oil for use in these studies.

The authors have declared no conflict of interest.

\section{References}

[1] Heiss, E., Herhaus, C., Klimok, B. H., Gerhanser, C., Nuclear factor- $\mathrm{\kappa B}$ is a molecular target for sulforaphane-mediated anti-inflammatory mechanisms. J. Biol. Chem. 2001, 276, $32008-32015$.

[2] Ganey, P. E., Barton, Y. W., Kinser, S., Sneed, R. A., et al., Involvement of cyclooxygenase-2 in the potentiation of allyl alcohol-induced liver injury by bacterial lipopolysaccharide. Toxicol. Appl. Pharmacol. 2001, 174, 113-121.

[3] Bitler, C. M., Viale, T. M., Damaj, B., Crea, R., Hydrolyzed olive vegetation water in mice has anti-inflammatory activity. J. Nutr. 2005, 135, 1475-1479.

[4] Feng, L., Xia, Y., Garcia, G. E., Hwang, D., Wilson, C. B., Involvement of reactive oxygen intermediates in cyclooxygenase-2 expression induced by interleukin-1, tumor necrosis factor-alpha, and lipopolysaccharide. J. Clin. Invest. 1995, $95,1669-1675$.

[5] Smith, W. L., Langenbach, R., Why there are two cyclooxygenase isozymes. J. Clin. Invest. 2001, 107, 1491-1495.

[6] Meade, E. A., Smith, W. L., De Witt, D. L., Differential inhibition of prostaglandin endoperoxide synthase (cyclooxygenase) isozymes by aspirin and other nonsteroidal anti-inflammatory drugs. J. Biol. Chem. 1993, 268, 6610-6614.

[7] Gilroy, D. W., Tomlinson, A., Willoughby, D. A., Differential effects of inhibition of isoforms of cyclooxygenase (COX-1, COX-2) in chronic inflammation. Inflamm. Res. 1998, 47, $79-85$.

[8] Bateman, D. N., NSAIDs: Time to re-evaluate gut toxicity. Lancet 1994, 343, 1051-1052.

[9] Barnes, P. J., Nuclear factor-кB. Int. J. Biochem. Cell Biol. 1997, 29, 867-870. 
[10] Aggarwal, B. B., Shishodia, S., Suppression of the nuclear factor-kappaB activation pathway by spice-derived phytochemicals: Reasoning for seasoning. Ann. N. Y. Acad. Sci. 2004, 1030, 434-441.

[11] Clegg, A. J., Composition and related nutritional and organoleptic aspects of palm oil. J. Am. Oil. Chem. Soc. 1973, 50, $321-324$.

[12] Manorama, R., Rukmini, C., Nutritional evaluation of crude palm oil in rats. Am. J. Clin. Nutr. 1991, 53, 1031S-1033S.

[13] Goh, S. H., Hew, N. F., Norhanom, A. W., Yadav, M., Inhibition of tumour promotion by various palm-oil tocotrienols. Int. J. Cancer 1994, 57, 529-531.

[14] Guthrie, N., Gapor, A., Chambers, A. F., Carroll, K. K., Inhibition of proliferation of estrogen receptor-negative MDAMB-435 and -positive MCF-7 human breast cancer cells by palm oil tocotrienols and tamoxifen, alone and in combination. J. Nutr. 1997, 127, 544S-548S.

[15] Takahashi, K., Loo, G., Disruption of mitochondria during tocotrienol-induced apoptosis in MDA-MB-231 human breast cancer cells. Biochem. Pharmacol. 2004, 67, 315324.

[16] Sylvester, P. W., Shah, S. J., Samant, G. V., Intracellular signaling mechanisms mediating the antiproliferative and apoptotic effects of $\gamma$-tocotrienol in neoplastic mammary epithelial cells. J. Plant Physiol. 2005, 162, 803-810.

[17] Serbinova, B., Kagan, Y., Han, D., Packer, L., Free radical recycling and intramembrane mobility in the antioxidant properties of alpha-tocopherol and alpha-tocotrienol. Free Radic. Biol. Med. 1991, 10, 263-275.

[18] Tomeo, A. C., Geller, M., Watkins, T. R., Gapor, A., Bierenbaum, M. L., Antioxidant effects of tocotrienols in patients with hyperlipidemia and carotid stenosis. Lipids 1995, 30, 1179-1183.

[19] Sen, C. K., Khanna, S., Roy, S., Packer, L., Molecular basis of vitamin E action. Tocotrienol potently inhibits glutamateinduced pp $60^{\mathrm{c}-\mathrm{Src}}$ kinase activation and death of HT4 neuronal cells. J. Biol. Chem. 2000, 275, 13049-13055.

[20] Osakada, F., Hashino, A., Kume, T., Katsuki, H., et al., Alpha-tocotrienol provides the most potent neuroprotection among vitamin $\mathrm{E}$ analogs on cultured striatal neurons. Neuropharmacology 2004, 47, 904-915.

[21] Kamat, J. P., Devasagayam, T. P. A., Tocotrienols from palm oil as potent inhibitors of lipid peroxidation and protein oxidation in rat brain mitochondria. Neurosci. Lett. 1995, 195, $179-182$.

[22] Nesaretnam, K., Devasagayam, T. P. A., Singh, B. B. Basiron, Y., Influence of palm oil or its tocotrienol-rich fraction on the lipid peroxidation potential of rat liver mitochondria and microsomes. Biochem. Mol. Biol. Int. 1993, 30, $159-167$.

[23] Conte, C., Floridi, A., Aisa, C., Piroddi, M., et al., Gammatocotrienol metabolism and antiproliferative effect in prostate cancer cells. Ann. N. Y. Acad. Sci. 2004, 1031, 391-394.

[24] Qureshi, A. A., Bradlow, B. A., Brace, L., Manganello, J., et al., Response of hypercholesterolemic subjects to administration of tocotrienols. Lipids 1995, 30, 1171-1177.

[25] Minhajuddin, M., Beg, Z. H., Iqbal, J., Hypolipidemic and antioxidant properties of tocotrienol rich fraction isolated from rice bran oil in experimentally induced hyperlipidemic rats. Food Chem. Toxicol. 2005, 43, 747-753.
[26] Ahn, K. S., Sethi, G., Krishnan, K., Aggarwal, B. B., $\gamma$-Tocotrienol inhibits nuclear factor- $\mathrm{\kappa B}$ signaling pathway through inhibition of receptor-interacting protein and TAK1 leading to suppression of antiapoptotic gene products and potentiation of apoptosis. J. Biol. Chem. 2007, 282, 809-820.

[27] Tsai, S. H., Lin-Shaiu, S. Y., Lin, J. K., Suppression of nitric oxide synthase and the down-regulation of the activation of NFkappaB in macrophages by resveratrol. Br. J. Pharmacol. $1999,126,673-680$.

[28] Gau, R. J., Yang, H. L., Chow, S. N., Suen, J. L., Lu, F. J., Humic acid suppresses the LPS-induced expression of cellsurface adhesion proteins through the inhibition of NF- $\mathrm{KB}$ activation. Toxicol. Appl. Pharmacol. 2000, 166, 59-67.

[29] Chen, Y. H., Lin, S. J., Ku, H. H., Shiao, M. S., et al., Salvianolic acid B attenuates VCAM-1 and ICAM-1 expression in TNF-alpha-treated human aortic endothelial cells. J. Cell. Biochem. 2001, 82, 512-521.

[30] Sen, C. K., Khanna, S., Roy, S., Tocotrienols: Vitamin E beyond tocopherols. Life Sci. 2006, 78, 2088-2098.

[31] Landry, D. W., Oliver, J. A., The pathogenesis of vasodilatory shock. New. Engl. J. Med. 2001, 345, 588-595.

[32] Höcherl, K., Dreher, F., Kurtz, A., Bucher, M., Cyclooxygenase-2 inhibition attenuates lipopolysaccharide-induced cardiovascular failure. Hypertension 2002, 40, 947-953.

[33] Zhang, C., Walker, L. M., Hinson, J. A., Mayeux, P. R., Oxidant stress in rat liver after lipopolysaccharide administration: Effect of inducible nitric-oxide synthase inhibition. $J$. Pharmacol. Exp. Ther. 2000, 293, 968-972.

[34] Brouet, I., Ohshima, H., Curcumin, an anti-tumour promoter and anti-inflammatory agent, inhibits induction of nitric oxide synthase in activated macrophages. Biochem. Biophys. Res. Commun. 1995, 206, 535-540.

[35] Pan, M. H., Lin-Shiau, S. Y., Ho, C. T., Lin, J. H., Lin, J. K., Suppression of lipopolysaccharide-induced nuclear factor$\kappa \mathrm{B}$ activity by theaflavin-3,3'-digallate from black tea and other polyphenols through down-regulation of IкB kinase activity in macrophages. Biochem. Pharmacol. 2000, 59, 357-367.

[36] Surh, Y. J., Chun, K. S., Cha, H. H., Han, S. S., et al., Molecular mechanisms underlying chemopreventive activities of anti-inflammatory phytochemicals: Down-regulation of COX-2 and iNOS through suppression of NF-kappa B activation. Mutat. Res. 2001, 480-481, 243-268.

[37] Reiter, E., Jiang, Q., Christen, S., Anti-inflammatory properties of $\alpha$ - and $\gamma$-tocopherols. Mol. Aspects Med. 2007, 28, $668-691$.

[38] Jiang, Q., Elson-Schwab, I., Courtemanche, C., Ames, B. N., Gamma-tocopherol and its major metabolite, in contrast to alpha-tocopherol, inhibit cyclooxygenase activity in macrophages and epithelial cells. Proc. Natl. Acad. Sci. USA 2000, 97, 11494-11499.

[39] O'Banion, M. K., COX-2 and Alzheimer's disease: Potential roles in inflammation and neurodegeneration. Expert Opin. Investig. Drugs 1999, 10, 1521-1536.

[40] Hinz, B., Kraus, V., Pahl, A., Brune, K., Salicylate metabolites inhibit cyclooxygenase-2-dependent prostaglandin $\mathrm{E}(2)$ synthesis in murine macrophages. Biochem. Biophys. Res. Commun. 2000, 274, 197-202.

[41] Baeuerle, P. A., Henkel, T., Function and activation of NFkappa B in the immune system. Annu. Rev. Immunol. 1994, $12,141-179$ 
[42] Evans, D. A., Hirsch, J. B., Dushenkov, S., Phenolics, inflammation and nutrigenomics. J. Sci. Food Agric. 2006, 86, 2503-2509.

[43] Szczepanik, A. M., Funes, S., Petko, W., Ringhein, G. E., IL4, IL-10 and IL-13 modulate A beta(1-42)-induced cytokine and chemokine production in primary murine microglia and a human monocyte cell line. J. Neuroimmunol. 2001, 113, 4962.

[44] Abramson, S. B., Weaver, A. L., Current state of therapy for pain and inflammation. Arthritis Res. Ther. 2005, 7, S1 -S6.

[45] Hart, P. H., Brand, C., Carson, C. F., Riley, T. V., et al., Terpinen-4-ol, the main component of the essential oil of Melaleuca alternifolia (tea tree oil), suppresses inflammatory mediator production by activated human monocytes. Inflamm. Res. 2000, 49, 619-626.

[46] Juergens, U. R., Engelen, J., Racke, K., Stober, M., et al., Inhibitory activity of 1,8-cineol (eucalyptol) on cytokine production in cultured human lymphocytes and monocytes. Pulm. Pharmacol. Ther. 2004, 17, 281-287.

[47] Birringer, M., Pfluger, P., Kluth, D., Landes, N., BrigeliusFlohe, R., Identities and differences in the metabolism of tocotrienols and tocopherols in HepG2 cells. J. Nutr. 2002, 132, 3113-3118.

[48] Yap, S. P., Yuen, K. H., Wong, J. W., Pharmacokinetics and bioavailability of alpha-, gamma- and delta-tocotrienols under different food status. J. Pharm. Pharmacol. 2001, 53, $67-71$.

[49] O'Byrne, D., Grundy, S., Packer, L., Devaraj, S., et al., Studies of LDL oxidation following $\alpha-, \gamma$-, or $\delta$-tocotrienyl acetate supplementation of hypercholesterolemic humans. Free Radic. Biol. Med. 2000, 29, 834-845.
[50] Mustad, V. A., Smith, C. A., Ruey, P. P., Edens, N. K., DeMichele, S. J., Supplementation with 3 compositionally different tocotrienol supplements does not improve cardiovascular disease risk factors in men and women with hypercholesterolemia. Am. J. Clin. Nutr. 2002, 76, 1237-1243.

[51] Raederstorff, D., Elste, V., Aebischer, C., Weber, P., Effect of either gamma-tocotrienol or a tocotrienol mixture on the plasma lipid profile in hamsters. Ann. Nutr. Metab. 2002, 46, 17-23.

[52] Patel, V., Khanna, S., Roy, S., Ezziddin, O., Sen, C. K., Natural vitamin $\mathrm{E}$ alpha-tocotrienol: Retention in vital organs in response to long-term oral supplementation and withdrawal. Free Radic. Res. 2006, 40, $763-771$.

[53] Yap, S. P., Yuen, K. H., Lim, A. B., Influence of route of administration on the absorption and disposition of alpha-, gamma- and delta-tocotrienols in rats. J. Pharm. Pharmacol. 2003, 55, 53-56.

[54] Okabe, M., Oji, M., Ikeda, I., Tachibana, H., Yamada, K., Tocotrienol levels in various tissues of Sprague-Dawley rats after intragastric administration of tocotrienols. Biosci. Biotechnol. Biochem. 2002, 66, 1768-1771.

[55] Ikeda, S., Tohyama, T., Yoshimura, H, Hamamura, K., et al., Dietary $\alpha$-tocopherol decreases $\alpha$-tocotrienol but not $\gamma$-tocotrienol concentration in rats. J. Nutr. 2003, 133, 428-434.

[56] Sen, C. K., Khanna, S., Roy, S., Tocotrienols in health and disease: The other half of the natural vitamin E family. Mol Aspects Med. 2007, 28, 692-728.

[57] Tan, B., Appropriate spectrum vitamin E and new perspectives on desmethyl tocopherols and tocotrienols. J. Am. Nutra. Assoc. 2005, 8, 35-42. 